\title{
The Diurnal and Nocturnal Floral Scent of Dracaena fragrans (L.) Ker Gawl. in Thailand
}

\author{
Jakaphun Julsrigival $^{{ }^{*} \text {, Sarinya Julsrigival }}{ }^{2}$, and Sunee Chansakaow ${ }^{1}$ \\ ${ }^{1}$ Department of Pharmaceutical Sciences, Faculty of Pharmacy, Chiang Mai \\ University, Chiang Mai 50200, Thailand \\ ${ }^{2}$ Regional Medical Sciences Center 1 Chiang Mai, Department of Medical \\ Sciences, Ministry of Public Health, Chiang Mai 50180, Thailand
}

*Corresponding author.E-mail: jakaphun@gmail.com https://doi.org/10.12982/CMUJNS.2020.0004

Received: July 19, 2018

Revised: May 16, 2019

Accepted: May 31, 2019

\begin{abstract}
Dracaena fragrans (L.) Ker Gawl., with its green leaves and attractive shape, is a popular ornamental plant in Thailand, used for both interior decorating and outdoor landscaping. Its fragrant flowers only bloom at night. This study investigated the volatile chemicals from the flowers of D. fragrans during the day and night. Volatile compounds were extracted by Head Space Solid Phase Micro-extraction (HS-SPME) technique and determined by Gas Chromatography-Mass Spectrometry (GC-MS). Thirty compounds were identified; sesquiterpenes were the most prevalent ( $\alpha$-farnesene, 23.1-50.8\%). The composition of the volatile compounds from the flowers differed between day and night.
\end{abstract}

Keywords: Dracaena fragrans, Volatile compounds, GC-MS, HS-SPME

\section{INTRODUCTION}

Dracaena fragrans (L.) Ker Gawl. (Asparagaceae) is a shrub with a vertical stem that can grow to than $15 \mathrm{~m}$ in height. Its leaves are green and lorateoblanceolate. Inflorescences are erect and located at the terminal branch. Its flowers are white with a red to purple line through the center; they bloom in the nighttime (Bos, 1984; Hyde et al., 2018).

D. fragrans is one of the world economic plants (Wiersema and Leon, 2013). It is used as an ornamental plant in wedding ceremonies and in folk medicine to ward off witchcraft (Kakudidi, 2004). It has many ethnomedicinal usages, including boiling the roots in water and using to fight illness (Moshi et al., 2012), collecting rainwater from its leaves to treat ear pain, using the 
decoction of its bark to treat malnutrition (Lacroix et al., 2011), and squeezing or chewing its leaves and roots to induce labor (Kamatenesi-Mugisha and OryemOriga, 2007). It has also been reported to have antimalarial activity (Lacroix et al., 2011) and to be an acetylcholinesterase inhibitor (Calderon et al., 2010). In addition, $D$. fragrans can reduce on pollutants such as bisphenol a, formaldehyde, toluene and xylene (Wolverton 1997; Saiyood et al., 2010).

In Thailand, D. fragrans (known as wassana in Thai, or lucky plant) is popular as an ornamental plant, both indoors and outdoors, easily growing in both. The flowers bloom infrequently, so Thais believe it brings the owner good luck when it does. The fragrant flowers usually bloom at night. The previous work has been already reported only 2 time of sampling (buds and flowers were collected at $2 \mathrm{pm}$ and $6 \mathrm{pm}$, Modak Dhar et al., 2013). No study has reported on variations in the volatile compounds of this plant from day to night. The demand for active ingredients for cosmetic and perfumery use is rapidly grown. The natural substances are preferred and can enhance the economic valued. But, in nature, plant volatile compounds are produced at a low level and depended on many factors such as light, temperature, environmental and other factors. The volatile compounds are rhythmically emitted with diurnal and nocturnal maximum. So, if the $D$. fragrans can produce volatile compounds not only in the night time but also in the day time, it will be a benefit for collecting and preparing the new usage source of volatile compounds for the cosmetic and fragrance industries.

This study characterized the diurnal and nocturnal volatile compounds from the flower of $D$. fragrans using Gas Chromatography-Mass Spectrometry (GC-MS) coupled with Head Space Solid Phase Micro-extraction (HS-SPME). The scent of this flower may be used for cosmetics and medicinal applications.

\section{Materials}

\section{MATERIALS AND METHODS}

Flowers of $D$. fragrans were collected from the Medicinal Plant Garden, Faculty of Pharmacy, Chiang Mai University, Chiang Mai, Thailand. Fresh flowers were gently picked from the plants every two hours over a 24-hour period (at 02:00, 04:00,.., 24:00). The samples were placed in 20-ml, screw-capped, glass vials (National Scientific, Rockwood, TN) and analyzed immediately. $n$-Alkane solution $\left(\mathrm{C}_{8}-\mathrm{C}_{20}\right)$ was purchased from Sigma-Aldrich Co.

\section{HS-SPME}

Volatile compounds of the flower samples were extracted using the method described by Julsrigival et al. (2013). Briefly, an AOC 5000 Combi PAL SPME holder (CTC Analytic AG., Switzerland) was equipped with a $65-\mu \mathrm{m}$ polydimethylsiloxane/divinylbenzene (PDMS/DVB) fiber assembly (Supelco, Bellfonte, PA). The fiber was pre-conditioned according to the manufacturer's 
specification $\left(250{ }^{\circ} \mathrm{C}\right.$ for $\left.30 \mathrm{~min}\right)$. The vials were pre-equilibrated and heated at $80{ }^{\circ} \mathrm{C}$ for $30 \mathrm{~min}$ with agitation at $500 \mathrm{rpm}$. Then the fiber was introduced into the GC-MS with 2 min desorption time.

\section{GC-MS}

The volatile compounds of the flower samples were analyzed by GC-MS using a Shimudzu GCMS-QP 2010Plus system (Shimudzu, Kyoto, Japan). Volatile compounds were separated by DB-5 MS capillary column $(30 \mathrm{~m} \times 0.25$ $\mathrm{mm}, 0.25 \mu \mathrm{m}$ film thickness; Agilent Technologies, Palo Alto, CA). The oven temperature was programmed as follows: initial temperature $60{ }^{\circ} \mathrm{C}$, increased to $200{ }^{\circ} \mathrm{C}$ at a rate of $5^{\circ} \mathrm{C} \mathrm{min}^{-1}$, then held for $10 \mathrm{~min}$; the injector and ion source temperatures were set at $180^{\circ} \mathrm{C}$ and $200^{\circ} \mathrm{C}$, respectively. The carrier gas (helium) was controlled at a flow rate of $1.0 \mathrm{~mL} \mathrm{~min}{ }^{-1}$. The electron impact mode was operated with an ionization voltage of $70 \mathrm{eV}$. The mass range was 40-400 amu. Volatile compounds were identified by comparing the obtained mass spectra of relevant chromatographic peaks with spectra of the WILEY 7 library and Kovats retention indices with other published mass spectra (Adam, 2007; NIST Chemistry WebBook). The retention indices were calculated for all volatile constituents using a homologous series of $n$-alkane under the same conditions of analysis.

\section{RESULTS}

Thirty volatile compounds of $D$. fragrans flowers were identified (Table $1)$. The main components were $\alpha$-farnesene (23.1-50.8\%), 3-hydroxy-4-phenyl2-butanone (2.2-18.2\%), and benzyl alcohol (3.3-15.6\%). The components were classified into eight categories: aldehydes, alcohols, esters, ketones, monoterpennes, sesquiterpenes, phenylpropenes, and other compounds. The main volatile compounds were from the sesquiterpene (26.2-59.0\%), alcohol (12.7-29.4\%), and phenylpropene group (7.5-24.4\%), respectively (Figure 1). 


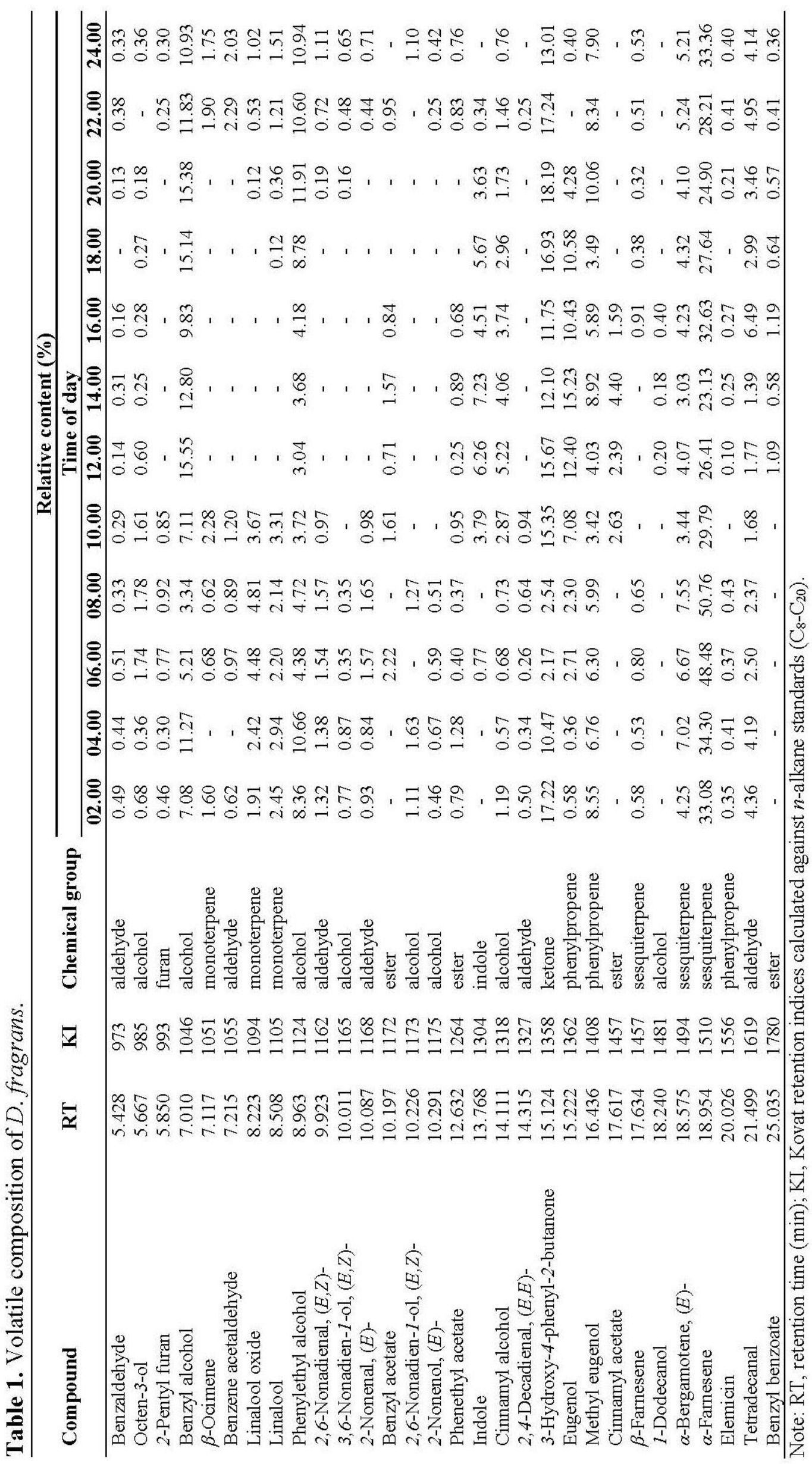




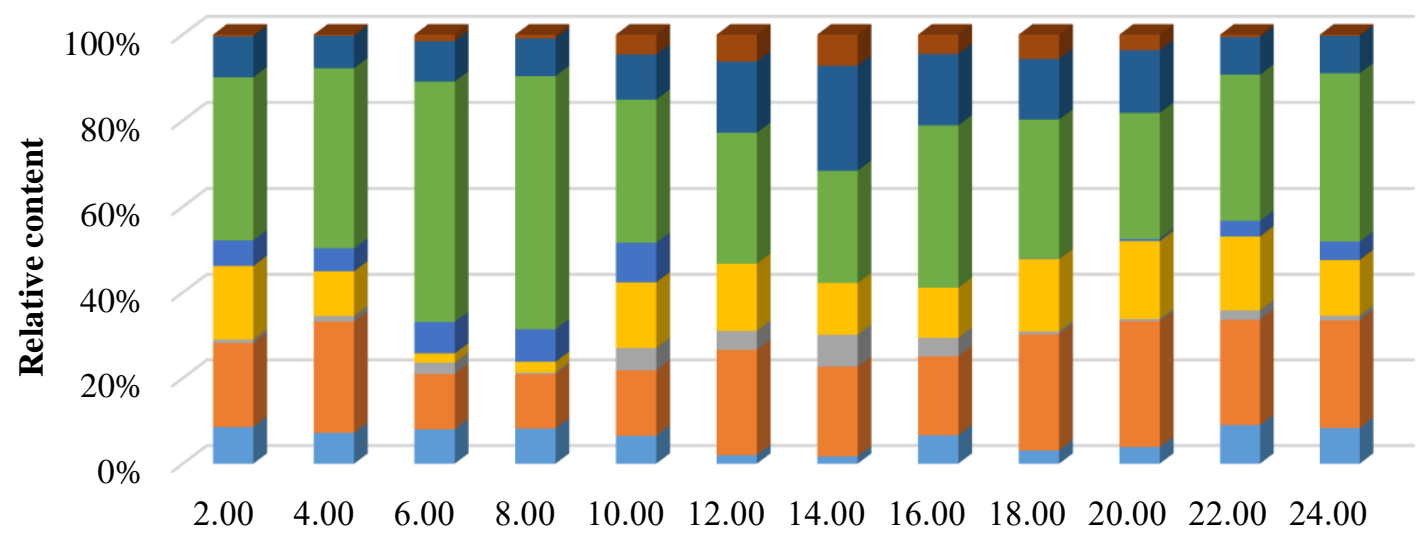

Time

$\square$ aldehyde $\square$ alcohol $\square$ ester $\square$ ketone $\square$ monoterpenne $\square$ sesquiterpene $\square$ phenylpropane $\square$ miscellneous

Figure 1. Chemical groups of D. fragrans.

\section{DISCUSSION}

The chemical composition of the volatile compounds of the flowers of $D$. fragrans varied with time of day. Usually, the flowers of $D$. fragrans bloom during the night - from evening until early morning, with its fragrance released then. The following chemicals were found in the samples collected from all time periods, i.e., both diurnally and nocturnally: benzyl alcohol, phenylethyl alcohol, cinnamyl alcohol, 3-Hydroxy-4-phenyl-2-butanone, methyl eugenol, $\alpha$-bergamotene, $(E)$-, $\alpha$-farnesene, and tetradecanal, with $\alpha$-farnesene the predominant compound in all sampled time periods (23.1-50.8\%). The following components were present mostly only during the blooming time (varied by compound, but ranging from 18:00 to 10:00): 2-pentyl furan; $\beta$-ocimene; benzene acetaldehyde; linalool oxide; linalool; 2,6-Nonadienal, (E,Z)-; 3,6-Nonadien-1ol, (E,Z)-; 2-Nonenal, $(E)$-; 2,6-Nonadien-1-ol, (E,Z)-; 2-Nonenol, $(E)$-; and 2, 4-decadienal, $(E, E)$-. Of these, the following compounds were not only present during the nighttime, but also increased over the course of the night, such as 2-pentyl furan; linalool oxide; linalool; 2,6-Nonadienal, (E,Z)-; 2-Nonenal, $(E)$; and 2-Nonenol, $(E)$ - (Figure 2). Linalool oxide and linalool were maximum produced at 8.00 and 10.00 (4.8\% and $3.1 \%)$. Volatile compounds were rhythmically produced. Cinnamyl acetate and 1-dodecanol were detected only in the midday samples (10:00-16:00 and 12:00-16:00, respectively). 


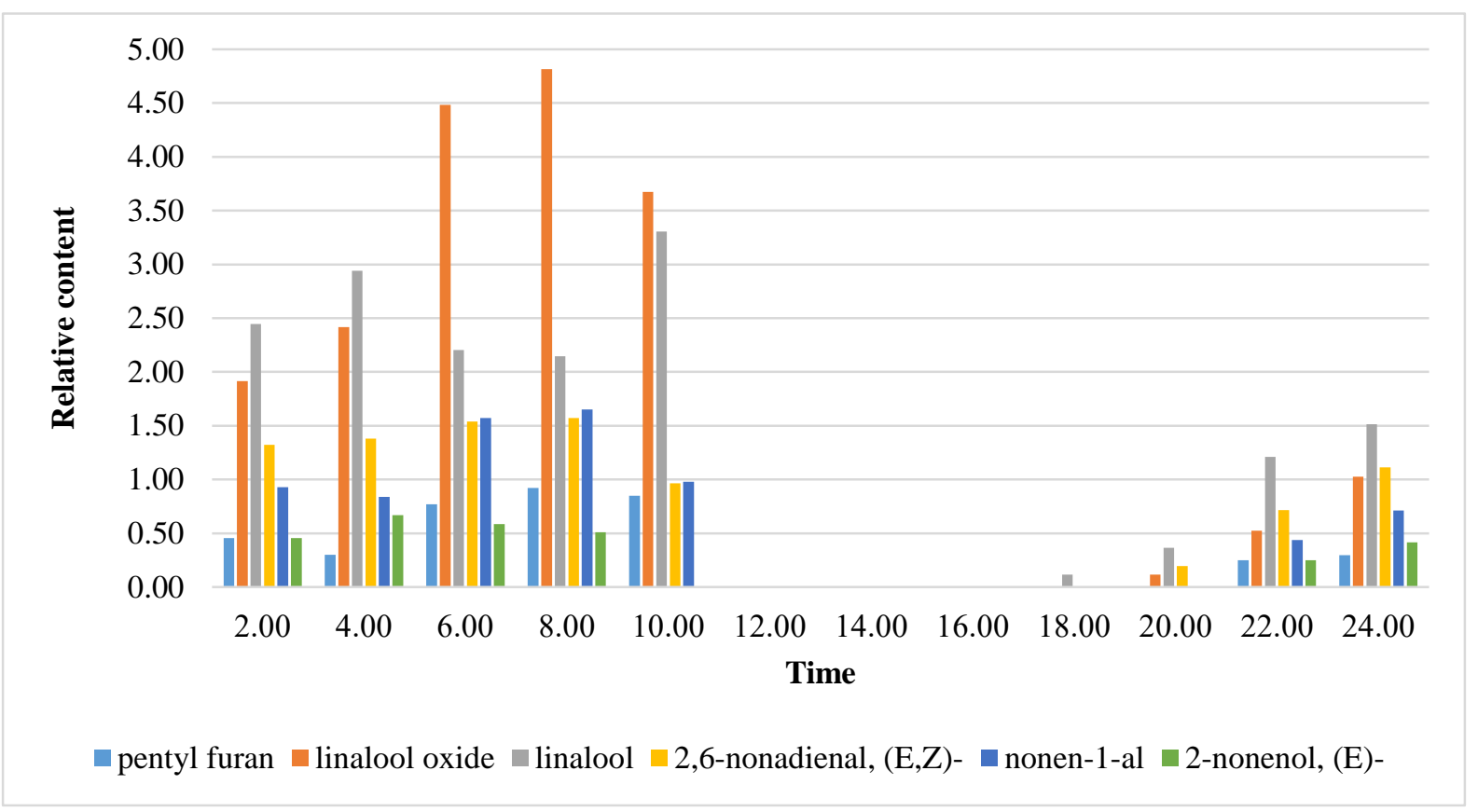

Figure 2. Selected chemical compounds of bloomed D. fragrans.

In contrast with the $\alpha$-farnesene of our study, Modak Dhar et al. (2013) reported that the major compounds of the essential oils analyzed from Dracaena flowers were butanoate and linalool produced at 18:00. The flowers were collected in Kolkata, India and the essential oils were extracted by immersing in the petroleum ether for 2 hour; differences in geography and extraction methods might account for this. Others have also reported $\alpha$-farnesene as the main compound in some flowers, such as Actinidia deliciosa (Nieuwenhuizen et al., 2009), Lonicera japonica (Schlotzhauer et al., 1996) and Murraya exotica (Raina et al., 2006).

Linalool, one of the compounds we found, has been reported to have many biological activities, including anti-inflammation, inducing relaxation, sedation and treating anxiety (Peana et al., 2002; Linck et al., 2009; Linck et al., 2010; Guzmán-Gutiérrez et al., 2015). Linalool is an important ingredient found in cosmetic products including body lotion, face cream, eau de toilette, fragrance cream and other toiletries (Letizia et al., 2003). $\alpha$-Farnesene was found in many fruit peels and flowers (Jaoui et al., 2017). The activities of $\alpha$-farnesene have been reported, including, plant defense (Zeng et al., 2017) and antioxidant activity (Celik et al., 2014).

The scents are used for communicating between plants and the other pollinators (Knudsen et al., 2006). Some night emitting compounds are attractive for pollinators such as moths (Morinaga et al., 2009; Dotterl et al., 2012), beetles (Maia et al., 2018).

This study found that time of day affected the composition of the volatile compounds found in the flowers of $D$. fragrans. $\alpha$-Farnesene was the most 
abundant compound emitted in all day time. However, some fragrances were produced in the early morning including linalool oxide and linalool.

\section{REFERENCES}

Adam, R.P. 2007. Identification of essential oil components by gas chromatography/mass spectrometry. Illinois: Allure Publishing Corporation.

Bos, J.J. 1984. Dracaena in West Africa. Drukkerij Veenman b.v, Wageningen. https://doi.org/10.3109/13880200903418514

Calderon, A.I., Cubilla, M., Espinosa, A., and Gupta, M.P. 2010. Screening of plants of Amaryllidaceae and related families for Panama as sources of acetylcholinesterase inhibitors. Pharmaceutical Biology. 48(9): 988-993.

Celik, K., Togar, B., Turkez, H., and Taspinar, N. 2014. In vitro cytotoxic, genotoxic, and oxidative effects of acyclic sesquiterpene farnesene. Turkish Journal of Biology. 38: 253-259. https://doi.org/10.3906/biy1309-55

Dotterl, S., Jahrei, K., Jhumur, U.S., and Jurgens, A. 2012. Temporal variation of flower scent in Silene otitis (Caryophyllaceae): a species with a mixed pollination system. Botanical Journal of the Linnean Society. 169: 447460. https://doi.org/10.1111/j.1095-83339.2012.01239.x

Guzmán-Gutiérrez, S.L., Bonilla-Jaime, H., Gómez-Cansino, R., and Reyes-Chilpa, R. 2015. Linalool and $\beta$-pinene exert their antidepressantlike activity through the monoaminergic pathway. Life Sciences. 128(2015): 24-29.

Hyde, M.A., Wursten, B.T., Ballings, P., and Coates Palgrave, M. 2018. Flora of Zimbabwe: Species information: Dracaena fragrans [cited 2018 Jun 12]. Retrieved from https://www.zimbabweflora.co.zw/speciesdata/species. php?species_id=114620

Jaoui, M., Lewandowski, M., Offenberg, J.H., Docherty, K.S., and Kleindienst, T.E. 2017. Ozonolysis of $\alpha / \beta$-farnesene mixture: analysis of gas-phase and particulate reaction products. Atmospheric Environment (1994). 169: 175-192.

Julsrigival, J., Songsak, T., Kirdmanee, C., and Chansakaow, S. 2013. Determination of volatile constituents of Thai fragrant orchids by gas chromatography-mass spectrometry with solid-phase microextraction. Chiang Mai University Journal of Natural Sciences. 12(1): 43-57.

Kakudidi, E.K. 2004. Cultural and social uses of plants from and around Kibale National Park, Western Uganda. African Journal of Ecology. 42(Suppl. 1): 114-118.

Knudsen, J.T., Eriksson, R., Gershenzon, J., and Stahl, B. 2006. Diversity and distribution of floral scent. The Botanical Review. 72(1): 1-120. https://doi.org/10.1663/0006-8101(2006)72[1:DADOFS]2.0.CO;2 
Kamatenesi-Mugisha, M., and Oryem-Origa, H. 2007. Medicinal plants used to induce labour during childbirth in western Uganda. Journal of Ethnopharmacology. 109(2007): 1-9. https://doi.org/10.1016/j.jep.2006. 06.011

Lacroix, D., Prado, S., Kamoga, D., Kasenene, J., Namukobe, J., Krief, S., Dumontet, V., Mouray, E., Bodo, B., and Brunois, F. 2011. Antiplasmodial and cytotoxic activities of medicinal plants traditionally used in the village of Kiohima, Uganda. Journal of Ethnopharmacology. 133(2): 850-855. https://doi.org/10.1016/j.jep.2010.11.013

Letizia, C.S., Cocchiara, J., Lalko, J., and Api, A.M. 2003. Fragrance material review on linalool. Food and Chemical Toxicology. 41(7): 943-964. https://doi.org/10.1016/S0278-6915(3)00015-2

Linck, V.M., Silva, A.L., Figueiró, M., Caramão, E.B., Moreno, P.R.H., and Elisabetsky, E. 2010. Effects of inhaled linalool in anxiety, social interaction and aggressive behavior in mice. Phytomedicine. 17(8-9): 679683. https://doi.org/10.1016/j.phymed.2009.10.002

Linck, V.M., Silva, A.L., Figueiró, M., Piato, A.L., Herrmann, A.P., Birck, F.D., Caramao, E.B., Nunes, D.S., Moreno, P.R.H., and Elisabetsky, E. 2009. Inhaled linalool-induced sedation in mice. Phytomedicine. 16(4): 303-307. https://doi.org/10.1016/j.phymed.2008.08.001

Maia, A.C.D., Grimm, C., Schubert, M., Etl, F., Goncalves, E.G., Navarro, D.M.D.A.F., Schulz, S., and Dotterl, S. 2018. Novel floral scent compounds from night-blooming Araceae pollinated by cyclocephaline scarabs (Melolonthidae, Cyclocephalini). Journal of Chemical Ecology. 45(2): 204-213 http://doi.org/10.1007/s10886-018-1018-1

Modak Dhar, T., Maji, S.R., and Ghosh, M. 2013. The comparative analysis of essential oils of buds and flowers of Dracaena frangrans. Science and Culture. 79(1-2): 124-127.

Morinaga, S., Kumano, Y., Ota, A., Yamaoka, R., and Sakai, S. 2009. Day-night fluctuations in floral scent and their effects on reproductive success in Lilium auratum. Population Ecology. 51: 187-195.

Moshi, M.J., Otieno, D.F., and Weisheit, A. 2012. Ethomedicine of the Kagera region, north western Tanzania. part 3: plants used in traditional medicine in Kikuku village, Muleba district. Journal of Ethnobiology and Ethnomedicine. 8(14): 1-14. https://doi.org/10.1186/1746-4269-8-14

Nieuwenhuizen, N.J., Wang, M.Y., Matich, A., Green, S.A., Chen, X., Yauk, Y.K., Beuning, L.L., Nagegowda, D.A., Dudareva, N., and Atkinson, R.G. 2009. Two terpene synthases are responsible for the major sesquiterpenes emitted from the flowers of kiwifruit (Actinidia deliciosa). Journal of Experimental Botany. 60(11): 3203-3219. https://doi.org/10.1093/jxb/erp162 
Peana, A.T., D’Aquila, P.S., Panin, F., Serra, G., Pippia, P., and Moretti, M.D.L. 2002. Anti-inflammatory activity of linalool and linalyl acetate constituents of essential oils. Phytomedicine. 9: 721-726. https://doi.org/ 10.1078/094471102321621322

Raina, V.K., Verma, S.C., Dhawan, S., Khan, S., Ramesh, S., Singh, S.C., Yadav, A., and Srivastava, S.K. 2006. Essential oil composition of Murraya exotica from the plains of northern India. Flavour and Fragrance Journal. 21: 140-142. https://doi.org/10.1002/fft.1547

Saiyood, S., Vangnai, A.S., Thiravetyan, P., and Inthorn, D. 2010. Bisphenol A removal by the Dracaena plant and the role of plant associating bacteria. Journal of Hazardous Materials. 178(2010): 777-785. https://doi.org/ 10.1016/j.jhazmat.2010.02.008

Schlotzhauer, W., Pair, S.D., and Horvat, R.J. 1996. Volatile constituents from the flowers of Japanese Honeysuckle (Lonicera japonica). Journal of Agricultural and Food Chemistry. 44(1): 206-209. https://doi.org/10.1021/ jf950275b

Wiersema, J.H., and Leon, B. 2013. World economic plants. $2^{\text {nd }}$ ed. FL: CRC Press. p 255.

Wolverton, B.C. 1997. How to grow fresh air: 50 house plants that purify your home or office. NY: Penguin Books.

Zeng, L., Liao, Y., Li, J., Zhou, Y., Tang, J., Dong, F., and Yang, Z. 2017. $\alpha$-Farnesene and ocimene induce metabolite changes by volatile signaling in neighboring tea (Camellia sinensis) plants. Plant Science. 264: 29-36. https://doi.org/10.1016/j-plantsci.2017.08.005 